\title{
The concept of necessity under the GATT and national regulatory autonomy ${ }^{1}$
}

El concepto de necesidad bajo el GATT y la autonomía regulatoria nacional

Isabel Cristina Salinas Alcaraz ${ }^{2}$

Fecha de recepción: 5 de abril de 2015

Fecha de aprobación: 8 de Agosto de 2015

\section{Abstract}

The intrusive effects of the WTO on Members regulatory freedom have been a growing concern since the establishment of the WTO Dispute Settlement System (DSS). An assessment of the WTO case law exposes that the Appellate Body (AB) has introduced some elements within the necessity test under GATT (General Agreement on Tariffs and Trade) article XX which do not find support in the text of the agreement and are potentially invasive of countries regulatory autonomy. This paper examines the evolution of the WTO case law in relation to the necessity concept within GATT 1994. Finally, an adjustment in the application of the necessity test to make it more consistent with the GATT text and to achieve greater balance between free trade and WTO members' regulatory autonomy is suggested.

Keywords: WTO case law, GATT article XX, regulatory autonomy, necessity test.

1 El presente texto fue desarrollado en el marco de los estudios de maestría adelantados por la autora durante el 2014 en la Universidad de Melboure, Australia, para optar al título de Magister en Derecho.

2 Abogada, asesora de la Dirección de Inversión Extranjera y de servicios del Ministerio de Comercio, Industria y Turismo, Magíster en Derecho (LLM) University of Melbourne, Especialista en Derecho de los Negocios y Especialista en Derecho Comercial, docente de cátedra de la Institución Universitaria Esumer, Medellín. isabelsalinasalcaraz@yahoo.com 


\section{RESUMEN}

Los efectos intrusivos de la Organización Mundial del Comercio (OMC) en la libertad regulatoria de sus miembros ha sido una preocupación creciente desde el establecimiento del sistema de solución de diferencias. Una revisión de la jurisprudencia de la OMC evidencia que el órgano de apelación ha introducido algunos elementos al test de necesidad del artículo XX del GATT (Acuerdo General sobre Aranceles Aduaneros y Comercio), los cuales no encuentran soporte en el texto del acuerdo y son potencialmente invasivos de la autonomía regulatoria de los países. Este texto examina la evolución de la jurisprudencia de la OMC en relación con el concepto de necesidad en el GATT de 1994. Finalmente, se sugiere un ajuste en la aplicación del concepto de necesidad para hacerlo más consistente con el texto del GATT y alcanzar un mayor balance entre el libre comercio y la autonomía regulatoria de los miembros.

Palabras clave: jurisprudencia OMC, GATT artículo XX, autonomía regulatoria, test de necesidad. 


\section{INTRODUCTION}

According to Michael Ming Du (2011), the assurance of national regulatory autonomy constitutes a core principle to the success of the World Trade Organization (WTO) system. WTO members are entitled to pursue their domestic policy objectives and to choose the means for their fulfillment, provided they do not entail protectionist ends. The WTO agreements do not merely pursue free trade promotion but seek a balance between member's free trade commitments and the right of members to achieve non-trade related goals. In accordance with this premise, WTO agreement interpretations should attend to such balance.

Ming Du (2011) also noted that the intrusive effects of the WTO system on Members policy making freedom have been a growing concern since the establishment of the WTO. The WTO case law has acknowledged the right of Members to national policy space. However; the Dispute Settlement System (DSS) has been constantly questioned for invasion of countries regulatory autonomy.

Domestic regulations should emanate from national actors who, in contrast to international organizations, are more connected with domestic social realities and therefore, have the ability to respond to domestic needs, preferences and economic concerns.

The mentioned author additionally reported that there is no guarantee that interpretations adopted by the WTO reflect the balance between trade liberalization and the policy freedom entitled to WTO members. Critics suggest that the vagueness and ambiguity with which the WTO rules have been drafted has been the cause of litigation over divergent interpretations. These litigations have resulted in recurrent unexpected interpretations by the DSS and have led to a reduction in the rights of WTO Members who have seen their policy freedom usurped by WTO panels and the Appellate Body's filling of interpretative gaps.

In 2002, Deborah Akoth Osiro noted that the WTO tribunal's interpretation of Article XX constitutes a clear example of this issue. Article XX contains a regime of exceptions to WTO commitments that are justified by the pursuit of certain non- 
protectionist goals. The provision contains an exhaustive list of legitimate objectives such as human health and protection of the environment. Some of the policy grounds listed in Article XX are required to have a relationship of necessity with the measure at issue. If a domestic regulation is identified as discriminatory, a country can justify such discrimination by demonstrating its character as necessary in the achievement of legitimate non trade goals.

An assessment of the case law in relation to Article XX exposes that the Appellate Body has demanded additional requirements from governments which has led to a very restricted application of Article XX and has contrived to make it a complex means of safeguarding national regulatory autonomy. In particular, the jurisprudential line in the concept of necessity has demonstrated that the Appellate Body has not shown 'deference to member's regulatory autonomy and whether it has kept the balance between free trade and liberalization is controversial' (Ming Du, 2010, pp. 1077-1102).

This paper will examine the evolution of WTO case law in relation to the necessity concept under the GATT 1994, taking into account the necessity criteria applied in the pre WTO era and the subsequent developments introduced by WTO jurisprudence. Attention will be given to the implications of WTO tribunal reasoning's on the right of Members to national regulatory autonomy.

It is highlighted by Gisele Kapterian (2010) that although the case law has presented some advances, uncertainty persists and reasoning's are contradictory between cases. Some of the elements introduced by the Appellate Body (AB) into the necessity test do not seem to find support in the GATT text. Particularly, the entitlement conferred to the WTO tribunal to evaluate the importance of the policy goal ${ }^{3}$ pursued by Members is potentially invasive of countries regulatory autonomy. This study finally suggests an adjustment of the necessity test to bring it more in line with the GATT text, thereby facilitating greater balance between free trade and the right of Members to national regulatory autonomy. (Kapterian, 2010).

3 See, WTO Appellate Body Report, Korea - Measures Affecting Imports of Fresh, Chilled and Frozen Beef (Korea - Beef), WT/DS/161/AB/R, adopted 11 December 2000, para 176. 


\section{NATIONAL REGULATORY AUTONOMY AND GATT ARTICLE XX}

In 2011, Ming Du noted that with the purpose of safeguarding essential societal values, governments often implement regulations or measures that can constitute barriers to trade. These measures often result in breaches of WTO rules and its underpinning principles of non-discrimination and open markets ${ }^{4}$. Trade liberalization is often in contradiction to essential government tasks which address other kinds of issues such as the protection of public health and environment.

Therefore, GATT Article XX establishes an exhaustive list of exceptions that are able to be invoked by members in relation to the breach of GATT rules. Osiro (2002) reported that the objective of this provision is to allow the implementation of certain measures that although entail certain forms of discrimination, are justifiable in pursuing certain regulatory aims distinct from trade liberalization. This provision implies recognition that certain societal values should receive priority over trade liberalization.

Article XX of the GATT makes some of the measures conditional on requirement of necessity in relation to the pursued objective. Specifically, the requirement of necessity is demanded when invoking the regimen of exceptions in relation to measures to promote public morals, to protect human life and health and to ensure compliance with GATT consistent national legislation.

Additionally, compliance with the requirements of the chapeau of Article XX is demanded when applying for an exception ${ }^{5}$. The chapeau prohibits the measure at issue from entailing an unjustifiable or arbitrary discrimination or a disguised restriction on international trade. Panels and the $A B$ have developed the concept of necessity in what has been referred to as the necessity test. According to Ming Du

4 See, Marrakesh Agreement Establishing the World Trade Organization, opened for signature 15 April 1994,1867 UNTS 3 (entered into force 1 January 1995).

5 WTO Appellate Body Report, United States - Standard for Reformulated and Conventional Gasoline (US Gasoline), WT/DS2/AAB/R, adopted 29 April 1996. 
(2011) and Osiro (2002) an analysis of the application of this test by WTO tribunals provides a measure of the WTO impact on the regulatory autonomy of members.

\section{THE DEVELOPMENT OF THE NECESSITY TEST AND ITS INCONSISTENCIES}

Ming Du (2010, 2011) and Kapterian (2010) consider that an assessment of the case law in relation to the necessity concept evidences inconsistent rulings that do not reflect the deference for member's regulatory autonomy expressed by the GATT text. Early Article XX case law was characterized by its accentuate interest in favor of trade liberalization and the undermining of National Regulatory Autonomy. In fact, under the GATT 1947, not a single Article XX invocation ever succeeded ${ }^{6}$.

\section{The least trade restrictive (LTR) test and its 'pro-trade' caracterization}

\section{US-Section 337}

According to Filippo Fontanelli (2013) and Osiro (2002), a first criterion to determine the necessity of a measure was the application of the least trade restrictive (LTR) test. In the US-Section 337 GATT dispute, the panel considered GATT XX (d) and stated that

A contracting party cannot justify a measure inconsistent with another WTO provision as 'necessary' if an alternative measure which it could be reasonably expected to employ and which is not inconsistent with other GATT provisions is available to it. By the same token, in cases where a measure consistent with other GATT provisions is not reasonably available, a contracting party is bound to use, among the measures reasonably available to it, that which entails the least degree of inconsistency with other GATT provisions. (GATT Panel Report, United States

6 See, GATT Panel Report, Thailand - Restrictions on Importation of and Internal Taxes on Cigarettes (ThailandCigarettes), BISD 37S/200; GATT Panel Report, United States - Section 337 of the Tariff Act of 1930 (US - Section 337), 1990 BISD 36S/34. 
- Section 337 of the Tariff Act of 1930 (US - Section 337), 1990 BISD 36S/345, 392-93, para 5.26)

Osiro (2002) stated that this criterion was applied in addition to the requirements of the chapeau of Article XX. This criterion also led to the consideration that the GATT inconsistency of a measure could be measured in accordance with 'scales of gravity' which allowed the establishment of the measure that was less GATT inconsistent. (Fontanelli, 2013; Kapterian, 2010)

\section{Thai Cigarettes case}

The application of this criterion was also illustrated by the case, Thai Cigarettes. The measure at issue was concerned with a ban on imported cigarettes; Thailand argued the protection of human life or health under Article XX (b). The panel applied the same criteria employed in the US-Section 337 dispute. However, in this case the panel restricted its assessment to the existence of WTO consistent measures and determined that various measures were able to be implemented by Thailand without contradicting WTO provisions, such as rigorous advertising regulation and marketing (Ming Du, 2010; Osiro, 2002).

This case was controversial (Kapterian, 2010; Ming Du, 2010) as the Panel omitted to consider the possible difficulties in the application of those measures and disregarded Thailand's arguments that the measures suggested restricted the achievement of state aims. The criticism was exacerbated by the fact that in being a developing country, Thailand lacked the resources necessary to implement some of the suggested alternative measures (Osiro, 2002).

Scholars claim that the Panel intruded on Thailand's right to choose its own level of protection, with assessment of alternative measures appearing focused on consistency with WTO provisions and not their ability to fulfill the goal of the original measure (Kapterian, 2010; Ming Du, 2010; Osiro, 2002).

7 GATT Panel Report, Thailand - Restrictions on Importation of and Internal Taxes on Cigarettes (Thailand Cigarettes), BISD 37S/200, 223 
The application of this criterion by panels was subject to great criticism because of their tendency to admit the existence of alternative less trade restrictive measures without a rigorous examination of the level of protection demanded by members and whether the measure is reasonably available to them.

Scholars have highlighted that the LRM test seems to require an extra obligation not included in the text of Article XX whereby, members have to examine the level of inconsistency of the alternative only against its impact upon trade. It is debatable how this obligation can maintain harmony with the right of members to establish their level of protection (Kapterian, 2010; Ming Du, 2010, 2011).

Furthermore, identification of the less trade restrictive measure can be difficult as there is no common criterion for such an assessment.

Members have expressed their confusion and disagreement with the rigid application of the LTR test. In United States-import prohibition of certain shrimp and shrimp products, United States argued that the LTR test 'required dispute settlement panels to dictate the specific measure to be adopted by the WTO member, since presumably there was only one measure among all the alternatives that was the least inconsistent with the GATT 1994'. Furthermore, United States claimed that the elements included in the LTR test were not able to be inferred from the text of Article XX. United States considered that application of the chapeau of Article XX would have been enough to prevent protectionist ends (Fontanelli, 2013; Ming Du, 2010, 2011).

According to Kapterian (2010), due to the manner in which it was applied in those cases, the LTRM is generally perceived by WTO Members as a disregard of their right to regulatory autonomy. The suggestion of alternative measures with less detrimental effects by Panels was considered an undue intrusion into domestic issues and the WTO was accused of being neglectful of the regulatory difficulties of national governments, with lack of consideration as to whether alternative measures were appropriate in light of member's social, political and economic circumstances. 
Schoenbaum (1997) has asserted that the role of the WTO tribunal should be to establish whether the measure is necessary to the achievement of the goal pursued and not if the measure in breach is a necessary deviation from WTO provisions.

\section{The unclear application of the weighing and balancing process}

\section{The Korea Beef Dispute ${ }^{8}$}

In the Korea-Beef dispute, Korea's implementation of a retail system, demanding the sale of imported beef and domestic beef in different stores, was considered inconsistent with Article III:4 and not justifiable under Article XX (d).

Korea argued that implementation of the measure was necessary to facilitate compliance with a regulation focused on preventing fraud that occurred through the labeling of imported beef as domestic. However, the WTO tribunal stated that less trade restrictive measures were available as WTO consistent measures were previously employed by Korea for other products.

As reported by Fontanelli (2013), Korea claimed that the panel incorrectly applied the consistency measure standard as it disregarded that the level of enforcement pursued by Korea was not the mere diminution of fraud but rather its elimination. However, according to some authors like Ming Du (2010), Kapterian (2010) and Mitchell and Henckels (2012), the decision was confirmed by the AB who, in what some have described as intrusive, considered it unlikely that Korea sought fraud elimination but rather, only its reduction. The view of the $A B$ was that fraud elimination implies the implementation of a different type of measure, such as a complete ban.

Mitchell and Henckels (2012) and also Donald Regan (2007) explained that in this dispute the $\mathrm{AB}$ clarified the concept of necessity and underscored that necessary is not

8 See, Korea-Measures Affecting Imports of Fresh, Chilled and Frozen Beef, adopted on 10 January 2001, [WT/ DS169/, Panel Report, WT/DS169/AB/R, AB Report]. (Korea Beef.); Deborah Akoth Osiro (2002). 
limited to that which is indispensable, of absolute necessity or inevitable. Measures with such characterization clearly satisfied the requirement of GATT Article XX (d) however, other measures may also be within the scope of this exception.

As reported by Regan (2007), the term necessary indicates a range of degree of necessity which, on one side refers to the concept of indispensable and on the other, making a contribution to. A necessary measure is closer to the concept of indispensable than making a contribution to.

The mentioned author also explains that excessive discussion has been generated by the fact that the $\mathrm{AB}$ seems to introduce what some have considered a cost benefit balancing test. The $\mathrm{AB}$ states that in every case the determination of whether a measure which, is not indispensable but, may nevertheless be "necessary", involves a process of weighing and balancing of a series of factors:

a) The extent to which the measure contributes to the realization of the end pursued. The higher the contribution, the more easily a measure might be considered as necessary.

b) The importance of the interests or values protected.

c) The degree to which the measure produces trade restrictions. A measure with a relatively slight impact upon imported products might more easily be considered as necessary, than a measure with intense or broader restrictive effects (Korea-Beef, WT/DS161.169/AB/R para 164).

In accordance with Regan (2007) great confusion arose because the tribunal did not develop with enough clarity the manner in which these elements interact with each other; the importance of the objective seems to be weighed against the other factors. For some, this process corresponds to a cost benefit balancing test, which can contradict the right of members to establish their own level of protection. Also, for Ming $\mathrm{Du}$ (2010) it is unclear how the importance of a measure, that pursues the achievement of any of the objectives recognized in Article XX, can be called upon for comparison to its trade restrictive costs. 
Regan (2007) argue that the AB referred to such a balancing test as applicable only to those cases in which the measure is not indispensable but nevertheless may be necessary. The examination seems to operate as a rescue for those measures that are not characterized as indispensable.

Ming Du (2010) and Mitchell and Henckels (2012) stated that confusion was later provoked by the fact that in its analysis, the $A B$ did not undertake the weighing -balancing process and returned to the LTRM test, citing the concept of necessity as established in United States-Section 337, 'the weighing and balancing process is encapsulated in the determination of whether a WTO consistent alternative measure or less WTO consistent measure and which is reasonably able to be employed is available' (Korea-Beef, WT/DS161.169/AB/R 165-166; Fontanelli, 2013).

One of the most controversial assertions made by the $A B$ is that a treaty interpreter may, in appropriate cases, consider the relative importance of the common interests or values that the law or regulation to be enforced is intended to protect and, 'the more vital or important those common interests or values are, the easier it would be to accept a measure as necessary' (Korea-Beef, WT/DS161.169/AB/R para 163; Kapterian, 2010; Mitchell \& Henckels, 2012).

It is worth mentioning that in this case, the analysis referred to Article XX (d) whereby, a measure necessary to secure compliance with laws or regulations which are not WTO inconsistent is justifiable under the regime of exceptions. Many types of laws and regulations can be included in this category' and for this reason the $\mathrm{AB}$ justified the entitlement of WTO tribunals to assess the importance to the objective. However, in subsequent cases such entitlement has been recognized when analyzing necessity under a different exception than Article XX (d) ${ }^{9}$.

According to Kapterian (2010), this entitlement could be perceived as unexpected for the text of Article XX (d) does not indicate that there is a different degree of

9 See, Brazil-Measures Affecting Imports of Retreaded Tyres, WT/DS332/AB/R, 3 December 2007; EC- Measures Affecting Asbestos and Asbestos-Containing Products, WT/DS135/AB/R, 12 March 2001, (EC-Asbestos). 
importance assigned to each regulatory purpose. Moved by its own perceptions, it appears that the $\mathrm{AB}$ is entitled to establish hierarchy between members' regulatory purposes. Such entitlement is in contradiction to the AB's intention to provide more deference to members' regulatory freedom.

Although the $\mathrm{AB}$ indicates that the importance of the regulatory goal must be considered, in reality it never provided any evaluation upon the level of importance attributable to Korea's goal (Regan, 2007). However, some argued that it indirectly conducted such an assessment when it suggested that the level of protection sought by Korea was fraud reduction and not fraud elimination (Ming Du, 2010; Mitchell \& Henckels, 2012).

Additionally, as reported by Regan (2007), the AB acknowledges that an alternative measure cannot be demanded even if it allows the achievement of the same domestic goal with less trade costs when it implies excessive administrative and enforcement costs. This statement maintains harmony with the rational that a measure could be necessary even if it is not indispensable.

According to the same author, there has been some discussion as to whether the comparison between the actual measure and its alternative, including consideration of the administrative cost, can correspond with a cost benefit analysis. However, scholars have explained that such assumption could constitute a misunderstanding as this assessment does not demand any weighing of the domestic benefit which is the intrinsic objective of the measure.

The $\mathrm{AB}$ clarified what can be considered an alternative measure and recognized that a substitute that is unable to achieve the same level of protection is not eligible as an alternative measure. In this sense the $\mathrm{AB}$ states, 'It is not open to doubt that Members of the WTO have the right to determine for themselves the level of enforcement of their WTO consistent laws and regulations' (Korea-Beef, WT/DS161.169/AB/R, para 173).

Scholars such as Osiro (2002) consider that the approach adopted in Korea Beef allows for an assessment that involves a teleological construction, with a less inconsistent test which includes the use of proportionality to determine the necessity of the measure. This change is said to facilitate for members the avenue of justifying 
the breach of WTO rules. WTO tribunals appear to have reduced their tendency to intrude upon members polices. Trade values no longer have an absolute prominence over domestic health environmental and safety concerns.

Although, this case displays some advances, criticisms persist, as a careful analysis of the Appellate Body's reasoning evidences some lack of clarity and inclusion into the necessity test of elements not stipulated in the text of Article XX (Kapterian, 2010; Mitchell \& Henckels, 2012; Ming Du, 2010).

Furthermore, subsequent decisions have reproduced the premises of Korea Beef; the weighing and balancing process and the recognition to members to establish their own level of protection. Several contradictions in the AB's reasoning in the Korea Beef case have still not been resolved in subsequent cases ${ }^{10}$.

\section{The French Asbestos Dispute ${ }^{11}$}

In the French Asbestos dispute, it was ruled that the French regulation prohibiting imports and production of asbestos was in violation of Article III however, the measure was justifiable in the protection of human life and health under GATT Article XX (b).

According to Kapterian (2010) and Regan (2007), the AB referred to the weighing and balancing process established in the Korea Beef case without explaining the reasons for its transference from the interpretation of GATT Article XX (d) to Article XX (b). Furthermore, the decision only analyzed each element separately and did not address or resolve the doubt of how the different elements interact with each other.

The $\mathrm{AB}$ reviewed the importance of the objective pursued by France and considered that the preservation of human life and health was both vital and important in the highest degree.

10 See, Canada-EC Asbestos Dispute; Ming Du (2010),

11 See EC-Measures Affecting Asbestos and Asbestos-Containing Products, WT/DS135/AB/R, 12 March 2001 
As reported by Ming Du (2010), the AB reinterred the right of Members to choose their level of protection and stated, ' $[\mathrm{I}] \mathrm{t}$ is undisputed that WTO Members have the right to determine the level of protection of health that they consider appropriate in a given situation'. France declared that its level of protection was the complete elimination of health risks associated with asbestos and based on this declaration, the $\mathrm{AB}$ considered that the alternative suggested by Canada of controlled use of Asbestos was unable to fulfill France's required 'level of health protection'. The AB deemed the French measure as necessary for there was no 'reasonably available' alternative.

This reasoning has been subject to criticism as there were some exceptions to the asbestos ban which drew doubt that the level of protection sought was 'the complete elimination of health risk'. The WTO tribunal could have drawn similar reasoning to that of Korea Beef and rejected Frances declared level of protection. This comparison highlights the weak position of Members before the appreciation of the WTO tribunal (EC-Asbestos, WT/DS135/AB/R, para 172-4; Ming Du, 2010).

Regan (2007) suggested that the $A B$ ignored the contradiction that exists between the right of members to choose their own level of protection and the application of the balancing process instituted by the Korea Beef case.

\section{US-Gambling ${ }^{12}$}

In US Gambling, the decision was under GATT Article XIV (a), a provision that is similar to GATT Article XX (a) in that an inconsistent measure can be justified when it is necessary to protect public morals. Due to the resemblance between the provisions, the process of weighing and balancing stated in Korea Beef was also invoked. Furthermore, the requirement that an alternative measure must preserve the level of protection chosen by the member was emphasized (Kapterian, 2010; Ming Du, 2010).

12 See Dominican Republic-Measures Affecting the Importation and Internal Sale of Cigarettes (DominicanRepublic - Cigarettes), WT/DS320/AB/R, adopted April 25, 2005. 
The weighing and balancing process was expressed in a different manner than in Korea Beef and the $\mathrm{AB}$ affirmed that the challenged measure should be compared with its alternatives and in light of the importance of the objective. For Ming Du (2010), this corresponds to a proportionality assessment. However, the issue with this statement is that it evidenced the uncertainty that exists for WTO Members in relation to the manner in which each element of the weighing process interacts with the other. Explanation of this interplay seems to change from one decision to the next.

The Gambling case stated that in understanding that necessity constitutes the defensive argument of a member whose measure has been challenged, the burden of proof rests on that member. Although, in those cases where the concept of necessity depends upon the lack of an alternative measure, the AB left it clear that the challenged Member is not required to scrutinize the inappropriateness of every plausible alternative measure, with it falling upon the complaining Member to propose "reasonably available alternatives" (US-Gambling, WT/DS285/AB/R 308; Kapterian, 2010; Mitchell \& Henckels, 2012).

\section{The Dominican Republic Cigarettes case ${ }^{13}$; clear evidence of WTO jurisprudence inconsistency}

As reported by Ming Du (2010) and Donald Regan (2007), in the Dominican Republic Cigarettes dispute the measure at issue was a tax stamp requirement on cigarette packaging to be affixed in the territory of Dominican Republic and under the control of its tax authorities. The measure was considered inconsistent with Article III:4 of GATT 1994 and Dominican Republic argued its justification under GATT XX (d). The AB considered that the measure was not necessary under the latter provision and that its application was discriminatory. In this decision the panel recognized that the tax stamp can constitute a viable instrument for tax collection. Furthermore, it was acknowledged as being of particular importance to a developing country to ensure tax collection and to prevent evasion. Moreover, it was considered

13 See Dominican Republic-Measures Affecting the Importation and Internal Sale of Cigarettes (DominicanRepublic - Cigarettes), WT/DS320/AB/R, adopted April 25, 2005. 
that the tax stamp did not have any significant restrictive effects for importations actually rose following its use. However, in considering the contribution of the measure to the objective, the panel determined that the measure was of limited effectiveness (WTO Appellate Body Report, para 71).

The $\mathrm{AB}$, when assessing the Panel's decision, did not perform any weighing and balancing process between the different elements of the measure. Its analysis was limited to consideration of whether reasonably available alternatives existed that were able to achieve the objective and concluded that '[T]he alternative of providing secure tax stamps to foreign exporters, so that those tax stamps could be affixed on cigarette packets in the course of their own production process, prior to importation, would be equivalent to the tax stamp requirement in terms of allowing the Dominican Republic to secure the high level of enforcement it pursues with regard to tax collection and the prevention of cigarette smuggling'(WTO Appellate Body Report, para 60).

The $\mathrm{AB}$ did not consider Dominican Republic's argument that the presence of the tax authority during the affixation of the tax stamp is more supportive in preventing tax evasion. The $\mathrm{AB}$ asserted that there was no evidence to assume that such tax collection requirement secures a zero tolerance level of enforcement (WTO Appellate Body Report, para 60).

Ming Du (2010) reported that this decision is subject to criticism as for some it is not clear under which assessment the $\mathrm{AB}$ established that the measure was necessary, as the only consideration appeared to be its limited effectiveness.

Kapterian (2010) argues that this case announced a tendency for modification of the necessity test whereby; the assessment of the contribution of the measure to the objective is the only relevant element. This tendency is supported by the fact that in this case the panel, when conducting its analysis after considering the measure's trade restrictiveness and the importance of the measure, followed with a separated stage in which it determined whether the measure was necessary. This case again confirms the uncertainty that characterizes WTO jurisprudence on the necessity test. 


\section{Brazil-Retreaded Tires ${ }^{14}$; some improvements}

As stated by Sébastien Thomas (2009) in Brazil-Retreaded Tires, Brazil invoked the regime of exceptions, relying upon GATT Article XX (b) to defend a ban on the importation of retreaded tires. Brazil claimed that due to the shorter lifespan of retreated tires, their imports entailed a higher increment of waste tires compared to that from new tires. Furthermore, waste tires represent a risk to human, animal and plant life or health through the liberation of noxious chemicals when burnt and by providing a breeding ground for mosquitos which can spread diseases such as dengue, yellow fever and malaria. Brazil exempted from the ban some retreated tires from Mercosur countries in order to comply with a decision from a Mercosur arbitral tribunal. Similarly, importation was allowed in some cases in compliance with court injunctions.

The $\mathrm{AB}$ found that Brazil's measure was temporarily justifiable as necessary to protect human, animal or plant life or health under Article XX (b) but the exemption conferred to Mercosur countries and the importation through judicial injunctions constituted unjustifiable discrimination between countries where the same conditions prevail and a disguised restriction on international trade.

Benn McGrady (2009) considered that in the Brazil Tires dispute the WTO tribunal seemed to provide more deference for a members' regulatory autonomy. The $A B$ was said to afford important clarification on the interpretation of the necessity test although, some issues persist. The $\mathrm{AB}$ reiterated the entitlement of Members to 'review the importance of the measures objective' (pp. 153-173).

The Panel, when analyzing the fulfillment of the elements of the test, considered that the Brazil measure was able to contribute to its objective of waste tire decline and the consequential reduction of risk to human, animal or plant life or health.

14 See, Brazil-Measures affecting imports of retreated tires, Report of the Appellate Body of 3 December 2007, WT/ $\mathrm{DS} 332 / \mathrm{AB} / \mathrm{R}$ 
The $\mathrm{AB}$ reaffirmed the right of Members to set their own level of protection and that the 'necessity test cannot reduce the level of protection establish by countries'. The $\mathrm{AB}$ insisted on the relevance of a panel to evaluate the importance of a members regulatory goal' (Report of the Appellate Body, para 140).

One of the most important findings in this case was that both the Panel and the $\mathrm{AB}$ recognized that in some cases certain complex issues such as those related to environment and health implied the implementation of complex policies.

In this sense, as noted by McGrady (2009), the WTO tribunal explained that in some cases measures that can be suggested as alternatives are actually complementary. It was stated that the measures suggested by EC of 'encouraging domestic retreading or improve the domestic retreadability of domestic used tires' (pp. 153-173) were accumulative and not a substitute. This approach increases the probability that certain measures can qualify as necessary.

A problem however, is that the WTO tribunal did not clarify the differences between complementary measures and alternative regulatory measures. There was an absence of specific rules that allow for determination as to whether the measure is complementary. This issue can confer an inappropriate discretion to the panel in determining whether or not a measure can be characterized as complementary. On the other hand, it could constitute a threat to the WTO treaty if interpreting what a complementary measure is came to be an extremely expansive process (McGrady, 2009).

\section{TOWARDS HARMONY WITH THE TEXT OF GATT ARTICLE XX}

The analysis conducted by Kapterian (2010) evidences the constant uncertainty that exists for Members due to the lack of consistency in WTO jurisprudence on the necessity test. Despite the test having evolved with some level of sophistication in recent decisions as noted by Mitchell and Henckels (2012); it still contains serious flaws that potentially undermine the right of Members to national regulatory autonomy (Kapterian, 2010). 
According to the mentioned authors, the weighing and balancing process developed in Korea Beef has assumed a different form each time it has been applied. It is still unclear how the various elements included in the weighing and balancing text interact with each other.

The entitlement of the WTO tribunal to review the importance of a measure's objective potentially entails interference with the right of countries to establish their policy priorities and detrimentally impacts upon the states right to choose its own level of protection.

As reported by Kapterian (2010) the WTO tribunal has expressly stated that the importance attributed to the objective pursued is a key determinant in the survival of the measure. This reasoning intensifies the risk that through the review of the importance of the measure a panel can undermine the right of members to invoke the application of a necessity exception. An interpretation more in accord with the text of GATT Article XX should be adopted and the weighing and balancing process should be excluded from the necessity analysis. Its introduction does not find GATT textual support (Kapterian 2010).

The only interpretation attributable to the term necessity, in accordance with the legal text, corresponds with the analysis of the measure contribution to the objective (Kapterian, 2010). The necessity expression implies that a closer link should exist between the objective pursued and the measure implemented compared to the link established for other exceptions provided within Article XX.

Inclusion of a weighing and balancing process into the concept of necessity implies the establishment of an extra requirement for the necessity exceptions, compared to those demanded under other exceptions cover by Article XX.

Kapterian (2010) reported that the importance of the objective pursued was determined by WTO members when drafting the agreement. The list of policy grounds enunciated in Article XX represents the important interests that members considered should not be compromised or open to examination in the pursuit of trade liberalization. 
Even in the case of article XX (d), whereby WTO consistent measures to secure compliance with laws and regulations are allowed, there is no justification for the WTO tribunal to assess the importance of the objective that the law or regulation intents to protect. It is sufficient that the law or regulation is not in breach of WTO regulations.

This does not mean that the measure is not subject to further analysis under the chapeau of Article XX 'the measure cannot constitute an unjustifiable, arbitrary or disguised restriction to trade' (Kapterian, 2010).

Scholars such as Ming Du (2010) and Mitchell and Henckels (2012) support the application of a weighing and balancing process as it can provide more flexibility to the necessity analysis because it allows for the consideration of a greater number of factors to be assessed which, in turn, may make it easier for a Member to justify the implementation of a measure. However, because this assessment does not find support in the legal text and it involves the examination of delicate factors, its introduction should be agreed upon by WTO Members.

\section{CONCLUDing REMARKS}

- WTO agreements seek a balance between member's free trade commitments and the right of members to achieve their public policy goals; a balance that the $A B$ 's interpretation should attend to. However, an assessment of the WTO case law in relation to the necessity test demonstrates that the AB has not shown deference to member's regulatory autonomy. Reasoning's present contradictions from one case to another and some of the elements introduced by the $\mathrm{AB}$ into the necessity test do not find support in GATT text. As a result, the case law does not reflect a balance between free trade and the right of members to national regulatory autonomy.

- Recent WTO case law on the necessity concept has offered some advances in the necessity test application. However, ambiguousness persists and reasoning's present contradictions from one case to another. Particularly, 
the weighing and balancing process introduced in the Korea Beef dispute is subject to great debate and the constant variations in its application have increased the uncertainty in its performance.

- Subsequent cases to Korea Beef evidence an intention of the WTO tribunal to show more deference for Member's regulatory autonomy. Although the entitlement conferred to WTO tribunals to evaluate the importance policy goal has led to justified questioning concerning the potential invasion of countries regulatory autonomy.

- The weighing and balancing process should be excluded from the necessity analysis; an interpretation more in accord with the text of the GATT Article XX should be adopted. The only admissible interpretation of the term necessity in accordance with the legal text is derived from the measures contribution to the objective and the close link that should exist between measure and objective in order to make it necessary. 


\section{REFERENCIAS}

Appellate Body Report, Brazil - Measures Affecting Imports of Retreaded Tyres (-BrazilRetreaded Tyres') (December 3, 2007). WT/DS332/AB/R.

Appellate Body Report, Korea - Measures Affecting Imports of Fresh, Chilled and Frozen Beef. (January 10, 2001). WT/DS169/AB/R.

Appellate Body Report, United States - Measures Affecting the Cross-Border Supply of Gambling and Betting Services (-US- Gambling'). (7 April 2005). WT/DS285/AB/R.

Fontanelli, F. (2013). Necessity Killed the GATT - Art XX GATT and the Misleading Rhetoric about 'Weighing and Balancing', European Journal of Legal Studies, Volume 5, Issue 2 (Autumn/Winter 2012/13), p 36 - 56

Kapterian, G. (2010). 'A Critique of the WTO Jurisprudence on Necessary', 59 (1) International and Comparative Law Quarterly 89.

Law: Reality or Rhetoric?', 13(4) Journal of International Economic Law 1077 (2010).

McGrady ,B. (2009).Necessity Exceptions in WTO Law: Retreaded Tyres, Regulatory Purpose and Cumulative Regulatory Measures, 12(1). Journal of International Economic Law 153.

Ming Du, M. (2010). 'Autonomy in Setting Appropriate Level of Protection under the WTO Law: Rhetoric or Reality? Volume 13, Issue 4. Journal of international Economic Law.

Ming Du, M. (2011). The Rise of National Regulatory Autonomy in the GATT/WTO Regime. Journal of International Economic Law 14(3):639-675

Mitchell, A. and Henckels, C. (October 1, 2012). Variations on a Theme: Comparing the Concept of 'Necessity' International Investment Law and WTO Law. Chicago Journal of International Law. 
Osiro, D. (2002). GATT/WTO Necessity Analysis: Evolutionary Interpretation and its Impact on the Authority of Domestic Regulation. Issue 2 Volume 29. Legal Issues of Economic Integration.

Regan, Donald H., 'Further Thoughts on the Role of Regulatory Purpose under Article III of the GATT' (2003) 37 Journal of World Trade, Issue 4.

Regan, D. (2007). 'The Meaning of "Necessary" in GATT Article XX and GATS Article XIV: The Myth of Cost-Benefit Balancing' 6 World Trade Review 3.

Reid, Emily, 'Regulatory Autonomy in the EU and WTO: Defining and Defending Its Limits' (2010) 44 Journal of World Trade, Issue 4.

Snell ,Jukka, 'True Proportionality and Free Movement of Goods and Services' (2000) 11 European Business Law Review, Issue 1.

Stelzer ,Robert, 'GATT Doctrine and the Limits of the WTO: An Investigation into Germany's Stem Cell Act' (2008) 42 Journal of World Trade, Issue 5.

The General Agreement on Tariffs and Trade (GATT) 1994

Thomas, S. (2009). Trade and environment under WTO rules after the Appellate Body report in Brazil-retreated tires. Vol. 4 Issue 1. Journal of International Commercial Law and Technology. 